\title{
Beyond the disguised friend: immanence, transcendence and glory in a Darwinian world
}

\author{
Christopher Southgate
}

\begin{abstract}
This paper takes as its starting point a quotation from the Anglican theologian Aubrey Moore, writing at the end of the 19th Century: 'Darwinism ... under the disguise of a foe, did the work of a friend'. I use this to discuss the problems for a scientifically-informed Christian theology that come from overstressing divine transcendence (which can lead to a sense of divine distance, even absence, from creation) or overstressing divine immanence (which can blur the distinction between God and the world). To achieve an appropriate balance between transcendence and immanence is also very important for an ecological theology.

The Christian Scriptures say little directly about transcendence and immanence, but they speak a great deal about God's glory. I present an understanding of divine glory as a sign of the divine reality, and show that this offers a way of speaking about both transcendence and immanence. In particular, the Incarnate Christ shows how God's immanence can take intense and particular form. As Christians are 'transformed from one degree of glory to another' (2 Cor. 3:18), they become signs of Christ the great sign of God. A Trinitarian God who draws believers into intimate fellowship with the divine life is transcendent in the radical character of God's immanence.
\end{abstract}

Keywords: Christology, 2 Corinthians, Darwinism, ecofeminism, ecotheology, glory, immanence, incarnation, providence, semiotics, transcendence, Trinity.

Many will recognise in the title of this chapter an echo of the famous quotation of Aubrey Moore in the collection of Anglican essays, Lux Mundi, edited by Charles Gore and published in 1889. Moore in his essay was exercised about how both divine transcendence and divine immanence could be preserved. He celebrated the rise of Darwin's theory, which had at first seemed like an enemy of faith, as being congenial to a theology that saw God's power as continuously immanent in creation. Moore writes:

The one absolutely impossible conception of God, in the present day, is that which represents Him as an occasional Visitor. Science had pushed the deist's God farther and farther away, and at the moment when it seemed as if He would be thrust out altogether, Darwinism appeared, and, under the disguise of a foe, did the work of a friend. It conferred on philosophy and religion an inestimable benefit, by shewing us that we must choose between two alternatives. Either God is everywhere present in nature, or He is nowhere. (1904 [1889]: 73).

This passage from Lux Mundi was much deployed by the late Arthur Peacocke (see e.g. Peacocke 2004). For thirty years until his death in 2006 Peacocke was an undisguised friend of theology in dialogue with science. He like Moore very much wanted to recover a sense of divine immanence, perceiving that theologians of physics tended to work with a transcendent designer, and that such a model would not do adequate justice to the biological world, evolving as that world has in a long process informed by the interplay of law and chance. 
But Moore's claim has always puzzled me. What he was determined to resist was a God of fitful creation, who had given rise to biological creatures through ordinary absence and occasional intervention. Darwin's proposal included the suggestion that one process, descent with modification under natural selection, could give rise to the great diversity of creatures on earth, and account for the extent of biological extinction. Moore saw this as congenial to a divine panimmanence. But the reason this claim puzzles me is that the Darwinian scheme is equally consonant, it seems to me, with a transcendent designer who designed the process and let it run without further involvement. Of itself, the world of evolution does not speak of divine immanence, and indeed the extent of the suffering in evolution, and the sense that the suffering of the weak drives the process of creaturely refinement by natural selection (Southgate 2008: 9), seems to sit uncomfortably with the immanent power of which Moore speaks.

That all serves as an opening parable to illustrate the struggle Christian theology can have with transcendence and immanence. Transcendence is very often imagined in spatial terms, and so easily connotes remoteness, lack of direct relationship with an evolving world. Indeed historically it easily moved into a deism in which God's loving engagement with the world is altogether absent. Immanence, on the other hand, too easily leads to blurring of the vital distinction between creator and creature. Deism and pantheism, then, are for the Christian theologian the Scylla and Charybdis of this debate (cf. Moltmann 1985: 98).

But why should this matter? Is this not just a game for systematicians to play in panelled seminar rooms while the great world spins on past them? There are two reasons in particular why all confessional theologians should care about this issue and struggle to articulate right understandings of transcendence and immanence.

First, a right balance between affirmations of divine immanence and transcendence seems to me essential for the giving of an account of divine providence how God is thought to interact with the flow of events. A strongly transcendent model of God tends to lead to a sense of divine absence, or to fitful intervention of the sort Moore so deplored, or to a model in which God is utterly temporally transcendent, present simultaneously to every moment of time, past, present and future. Although that latter model has many defenders I have always struggled to see how it gives rise to the sort of interactive engagement with the flow of history of which the Scriptures speak. Likewise it's difficult to develop a model of particular providence out of a model of God based on panimmanence.

Of course, a good model is not transcendence or immanence but both/and, yet this balance remains very hard to strike. And this matters enormously to the articulation of Christian faith, because the question, What on earth is God doing? lurks behind so much questioning of God, among believers and non-believers alike. That classic question in response to suffering - how could God allow this? - is at once a question about theodicy and a question about providence. In theology, providence and theodicy are inseparable twins.

So: the right articulation of divine transcendence and immanence can help form the springboard for articulating understandings of providence that take theodicy with all the seriousness it deserves. But my second reason for stressing the importance of this subject is if anything even more pressing. Questions of transcendence and immanence have been of vital importance in ecotheology. Over-emphasis on divine transcendence can be a distortion in the dialogue between theology and physics, but in ecotheology overemphasis on transcendence has been identified by many authors, especially ecofeminists, as deeply destructive of healthy understanding of the relationships between God, human beings, and the non-human creation. 
An overly transcendent, distanced model of God, absent master of the universe, can seem to license a view of human beings, created in the divine image, as themselves transcending creation; not quite a part of it, but rather the mastering representatives of the absent master. In a recent essay responding to climate change Sallie McFague describes traditional models of divine transcendence as 'no longer credible'. She goes on: 'Who can believe a supernatural, imperialistic, all-controlling super-person, imagined after a comic-book superhero?' (McFague 2017: 101). And as Clare Palmer pointed out long ago, even the innocent-sounding and very widely adopted image of humans as stewards of creation can carry connotations of divine absence and human mastery (Palmer 1992). And this language of mastery rather than relationship has all too often gone hand-in-hand with mastery of men over women.

It is twenty-five years since McFague published The Body of God: an ecological theology, an essay on immanence and transcendence that still bears re-reading today. After a fierce critique of what she calls political transcendence, extrapolating God as a kind of super-monarch, and negative transcendence, a series of abstractions trying to define God as without limit as to power, knowledge, benevolence, etc., McFague argues for radical transcendence-in-immanence. Because the world is as it were the body of God, every detail of it, rightly contemplated, reveals the transcendent awesomeness of the divine. The universe, she writes, 'serves as a deep reflecting pool of divine magnificence and grandeur' (McFague 1993: 154). To this 'organic' model of God's immanence McFague adds a component of divine agency (1993: 140). This has always seemed to me an uneasy fusion of models. How does generalised immanence generate particular agency? 1

I can however endorse McFague's sense that divine immanence cannot be confined to the historical event of the Incarnation of the divine Son in Jesus, but must extend to all universes, indeed all multiverses, and within them to the indwelling of all created entities. The agential component of McFague's model of divine immanence can be seen in her appeal to 'the incognito appearance of Christ wherever we see human compassion for the outcast and the vulnerable' (1993: 195).

Beyond McFague's critique, we may note that two of the central planks of orthodox Christian doctrine are potentially problematic for the balance of transcendence and immanence. The affirmation that God created ex nihilo, out of absolutely nothing, is seen by theologians as disparate as Catherine Keller, Whitney Bauman and Tom Oord (Keller 2002; Bauman 2009; Oord forthcoming) as being problematic for creation care. The underlying reason is that such a doctrine seems to privilege divine distance, divine transcendence. And Rosemary Radford Ruether identifies another source in Christianity of a tendency to accord superiority to transcendence over immanence. The divine principle immanent in the world became identified with the Logos, and through that, the Son of the Father. Ruether writes: 'This "Son-Father" metaphor is used to represent the immanence of God as "under" and derivative from divine transcendence' (Ruether 1998: $83)$.

So we find in ecotheologians and particularly ecofeminists a great wariness of divine transcendence, a fear that its superiority, spatially, politically, temporally, is embedded in the Christian tradition in deeply unhelpful ways. We tend to find therefore a desire in ecotheology to affirm rather a non-mastering immanence of the creator, with much emphasis on the feminine in God, and the role of the Spirit. Indeed the language of the Spirit does perhaps offer the most promising way to speak of the immanence of God,

\footnotetext{
${ }^{1}$ A problem also experienced by Peacocke in his formulations of divine action (e.g. Peacocke 2001: Chapter 5; 2007: 45-7; Clayton 2007).
} 
in a way that, to borrow the terminology of McFague, can be agential as well as organic (see McFague 1993: 139-40).

H. Paul Santmire is also exercised by the language of a God spatially transcendent, 'up there beyond', to whom human souls are drawn, out of this world of sin. But Santmire draws back from what he regards as the radical 'reconstructionist' approach he sees in much ecofeminism (Santmire 2002: Chapter 1). He prefers a 'revisionist' approach, rereading the Scriptures and re-raiding the tradition to give rise to a more eco-appropriate model, which nevertheless remains in evident continuity with the tradition. Interestingly he takes Luther as his exemplar of a theologian who took issue with an emphasis on the soul ascending to be with God in the above.

Santmire writes: "For Luther, God is always "God with us", immanent in our world, immediately active in the world of creation where we live, on our level' (Santmire 2008: 107). Luther's phrase about God's presence being 'in, with and under' was also a favourite phrase of Peacocke's, and influenced the way Arthur ended up formulating the co-suffering of God with all creatures that suffer (Peacocke 1998: 372). Santmire uses Luther's phrase as part of his critique of a 'theology of ascent' (2008: 92-105). He wants to insist that the Ascension of Christ should not make us think of God up and beyond. As God the Father is in, with and under all things, so is the ascended Son of God (Santmire 2008: 115). Santmire is led to propose a modification of the ancient Sursum Corda which opens the Eucharistic prayer in so many Christian churches. In place of the bidding 'Lift up your hearts', Santmire proposes the alternative 'Open your hearts', with the response 'We open them to the Lord' (2008: 162). This is a thought-provoking modification aimed at reinforcing a sense of God immanent in our midst, did we but have, spiritually, eyes to see and ears to hear.

Anne Primavesi, in her moving writings on gift exchange as the way the earth system ('Gaia') 'works', wants to move away from one of the key movements of the eucharist, the continual thanking of God for the gifts of the Earth (Primavesi 2003: 133). She claims that we lack the intuitions and concepts to model God in a post-Copernican, ecosystemically-aware world. Instead we should focus on gift-exchange with other elements of Gaia, aware that the affluent, food-glutted world of the West has lost a sense of the blessing attached to 'daily bread'. What Primavesi insists on is God's epistemological transcendence; we cannot rightly discern what it would be to thank God in thanking Gaia, so we should rather learn how to thank Gaia properly.

I want now to explore a different approach to the formulation of a helpful model of God and God's ways with the world. I note that actually the Christian Scriptures contain relatively few direct affirmations of God's transcendence, or yet of God's immanence, but they have plenty to say about God's glory.

I came to the study of God's glory out of years of wandering in the wastelands of theodicy. I began to see that ultimately all theodical schemes, even the less obviously flawed ones, are at best only partially satisfactory. I also noted that the Scriptures offer little in the way of theodicy, beyond the Deuteronomistic impulse to blame all misfortune on the sins and covenant-unfaithfulness of the people of God. The experience of the wisdom-teachers of Israel moves them beyond that neat and always tempting formulation, but it does not lead them to a better theory. The great drama on the theme of suffering that is the Book of Job does not lead to a nice formulation of the relation of God to suffering. And Jesus when asked about suffering is recorded by the Gospel writers as answering very enigmatically. In John 9 we read: 
His disciples asked him, 'Rabbi, who sinned, this man or his parents, that he was born blind?' Jesus answered, 'Neither this man nor his parents sinned; he was born blind so that God's works might be revealed in him' (Jn 9:2-3).2

And two chapters later we read in the story of Lazarus:

So the sisters sent a message to Jesus, 'Lord, he whom you love is ill.' But when Jesus heard it, he said, 'This illness does not lead to death; rather it is for God's glory, so that the Son of God may be glorified through it' (Jn 11:3-4).

What is going on in this language of revelation and glory? I come to the conclusion that what the language of divine glory tends to connote is a sign or array of signs of the depths of the divine reality (Southgate 2018: 8). Those depths are always to some extent hidden, but manifestation of glory is what makes them momentarily, partially, visible. This is very evident in the great theophanies of the Hebrew Bible, in Exodus, in Isaiah 6 and Ezekiel 1. In this last passage, fascinatingly, the sign of the glory of God takes human form. Ezekiel's vision no doubt influenced not only the visions in the Book of Daniel but also intertestamental writings such as the Book of Enoch, and arguably also the incarnational theology that emerges in the Gospel of John.

At once I need to enter a certain caveat. There are passages in which the glory of the Lord, the kavōd Yahweh, seems to connote not so much a sign of God as something much closer to the actual Godness of God in Godself. I think particularly of Ex 33:18f, where Moses, having seen all the theophanic manifestations of the divine kavōd, and even spoken to the Lord as a man speaks with a friend, still asks 'Show me your glory.' So the meaning of divine glory has to be seen on a spectrum from the purely semiotic to something much more ontological (Southgate 2018: 23-4). But here I shall pursue mainly the semiotic understanding of glory - glory as sign of the depths of the divine reality. Incidentally, if glory is understood in this way, then what Job receives in God's great speech from the whirlwind (Job Chs 38-41) is effectively a lecture on glory, a list of all the signs by which God's unique creative power can be recognised, a lecture indeed complete with powerpoint illustrations and plenty of opportunity for student interaction.

In this understanding of divine glory Jesus functions as the quintessential instance of such a sign. The Fourth Gospel tells us that Christ's glory is of the Father's only Son, full of grace and truth. In his ministry, and very particularly when he is lifted up on the Cross for the world's sake, Jesus shows us the character of God in the most powerful and direct way possible. And Jesus himself performs signs which reveal him as God's great sign - beginning, according to John, with changing water into wine, and leading as we have seen through the healing of the blind man and the raising of Lazarus, and ultimately to Jesus' 'hour' of being handed over to the powers of oppression and lifted up on Calvary.

At this point I need to introduce some of the categories of sign articulated by $\mathrm{C}$. S. Peirce, and here I am much indebted to the work of my colleague and collaborator Andrew Robinson, whose application of Peircean semiotics to Trinitarian theology is both innovative and generative (Robinson 2010; 2014). The nature of signs in themselves Peirce classified according to whether they are qualisigns, representing their objects by virtue of their sheer quality (the classic example being 'a colour-sample of paint or cloth'), sinsigns (singular occurrences, 'such as a leaf blown by the wind') or legisigns ('a sign replicated according to some rule for the purpose of signifying, as when a letter or word is written on a piece of paper') (Robinson 2010: 39-40). Peirce also categorized signs

2 All biblical quotations are from the New Revised Standard Version unless otherwise stated. 
according to the relation of the sign to the object, which can be that of an icon - a direct likeness - or an index, which 'represents its object by virtue of some direct relationship between the two such that the character that makes the index a sign would be lost if the object were removed' (2010: 119). A simple example would be a pointing finger. The third category of sign-object relations is what Peirce called a symbol. Note that this is a specific and technical use of the term 'symbol', meaning that the sign-object relation was by convention. Scripture functions as a symbolic 'legisign' - Christians read it as sign of the divine reality because of the established convention that it is Scripture, 'God-breathed' (2 Tim 3:16).

The great theophanies of the Hebrew Bible are most easily thought of as indexical 'sinsigns' - once-off occurrences pointing to what is signified - though they may also have been interpreted to have some iconicity, the remote and terrifying fire on the mountaintop actually being a likeness of the awesome holiness of the Lord. One of Robinson's most creative moves is to propose that, while particular incidents in Jesus' life reflect a range of sign-types, the overall quality of his life represented the life of God by virtue of its sheer quality. The 'colour' of that life is what can be most truly known of the 'colour' of God's own life (Robinson 2010: 123-8).

So we begin to see indications here of a journey of the divine glory. In the formation of Israel's relationship with its God, those theophanies pointing to the awesome presence of the divine reality are profoundly important, terrifying as is the kavod Yahweh as it appears in the cloud. Transcendence is pointed to - a transcendence of power and might as well of utter remoteness, utter holiness. Whereas in the New Testament, if we follow Robinson's suggestion, the sheer quality of the divine life is immanent within the quality of the life of the Incarnate Son, which therefore is iconic of the life of God.

And perhaps this sort of immanence starts to solve our problem about how divine immanence can be associated with agency. The immanence of God is intensified and particularised in the quality of the life of Jesus, and that life is active in drawing disciples into that quality of life. (Not that I am limiting divine action to this, but it does seem to me a very important locus of providence, operating as the hymn has it, 'soul by soul and silently'.) And we can extend this as McFague does to whatever human action is performed in love for the vulnerable, and (in terms of Matthew 25) thereby serves Christ.

Apart from the Gospel of John our other great New Testament source of insight into divine glory is the work associated with the Apostle Paul. And the classic locus of Paul's discussion of glory is the third and fourth chapters of his Second Letter to the Corinthians. Paul's complex reflection on Exodus 34 in the context of his new Spiritfilled communities culminates in this verse:

And all of us, with unveiled faces, seeing the glory of the Lord as though reflected in a mirror, are being transformed into the same image from one degree of glory to another (apo doxēs eis doxan); for this comes from the Lord, the Spirit. (2 Cor 3:18)

In interpreting this verse in the context of my theory of signs I do not underrate its exegetical complexities, which I address in much more detail in my monograph on glory (Southgate 2018: Chapter 5). With the majority of commentators I take 'the Lord' whose glory is contemplated to be the risen Christ. A big quandary in this verse is: what does it mean for believers to be transformed from one degree of glory to another? And what that strange phrase of Paul's apo doxés eis doxan suggests to me is that believers are, as they contemplate Christ crucified and risen, the quintessential sign of the divine reality, in a process of becoming more and more truly signs of that sign of God that is Christ. 
That re-expresses what Paul articulates in that other seminal text for his understanding of glory, Rom 8:29-30:

For those whom he foreknew he also predestined to be conformed to the image of his Son, in order that he might be the firstborn within a large family. And those whom he predestined he also called; and those whom he called he also justified; and those whom he justified he also glorified. 3

Being 'conformed to the image of' seems to me close to 'becoming a sign of'. Especially since in a number of Pauline passages the terms eikon and doxa are very close, almost interchangeable (Savage 1996: 147-50). So that is the journey of the Christian believer, putting on - to use another Pauline image - Christ, in such a way as to become a truer and truer sign of Christ, whom Paul calls 'the image of God', and I am calling the great and utterly faithful sign of God's nature.

The conference that led to this collection of essays took place in Lyon, famous as the base of the great 2 nd-Century theologian Irenaeus. One of Irenaeus' most famous sayings is rendered in Latin Gloria enim Dei vivens homo, vita autem hominis visio Dei. The first part of this saying is usually (if controversially) translated 'The glory of God is a human being fully alive'. In the interpretation of glory being offered here, this might be paraphrased: the glory (true sign of deep reality) of God is a human being become fully alive, as an authentic sign of the divine life within him or her. Less often translated is the second half of the saying, that the [authentic] human life is the contemplation of God. This saying then picks up the dual meaning in 2 Cor. 3:18 of the participle translated 'seeing [the glory of the Lord] as though reflected in a mirror'; that word (katoptrizomenoi) can also carry the connotation of reflecting that glory. Irenaeus offers us the same dual thought reversed - first he mentions the authentic human being's 'reflection' of the glory of God, and second the contemplation. For further discussion see Southgate 2018: Chapter 5.

I return here to Robinson's idea of Jesus's life as a qualisign of the life of God. In Jesus' case his actions functioned as various types of sign of the nature of God, but it was the overall quality of Jesus' life, its 'colour', that functioned most eloquently as a sign of the divine life. Roy Harrisville notes that in the Fourth Gospel 'the entire life of Jesus is described as a theophany' (Harrisville 2006: 216). And Hans Urs von Balthasar writes: 'Jesus bears witness to God as a man, by using the whole expressional apparatus of human existence from birth to death' (1982: 29). This is very helpful as we try to see how the believer can become progressively a truer sign of Christ, the great sign of God, when humans' individual actions are so full of muddle and mixtures of motives. The overall quality of human lives can still start to take on the colour of Christ's life. In a local community a single action may be very influential, it may serve as an indexical sinsign, a once-off pointing to the importance of God in that community, but over time it is the overall quality, the overall character of a life that speaks of God's life to that community. Frances Young quotes Gregory of Nyssa as writing, 'mercy and good deeds are works God loves; they divinize those who practice them and impress them into the likeness of goodness, that they may become the image of the Primordial Being' (Young 2013: 16).' It is as qualisigns that we are being transformed apo doxēs eis doxan. Paul's imagery is consistent with believers acting as a 'colour-sample' of Christ. He writes: 'For while we live, we are always being given up to death for Jesus's sake, so that the life of Jesus may be made visible in our mortal flesh' (2 Cor 4:11).

3 For a new study of glory in Paul working from this passage see Goranson Jacob and Wright 2018. 
What is this 'colour' of life that Jesus evinced and is the goal and destiny of believers' (individual and corporate) transformation? From all the Gospels we know that it will be infused by a continual turn to prayer. That key moment of disclosure at Emmaus suggests that the blessing of God's gifts will be absolutely characteristic, so much so as to give rise to instant recognition (Lk 24:30, cf. also Mk 8:6; 14:23, and Jn 6:11). From John we know that the 'colour' is 'full of grace and truth' (Jn 1:14), and so close to God through prayer as to be in the very 'bosom of the Father' (1:18). From Paul we know that it is a quality of life both cruciform and 'anastiform' - that is to say, it bears, indissolubly, the colours of Cross and Resurrection (Finlan 2007: 78). In her very moving reflections on her life with her profoundly disabled son Arthur, Young makes clear that she believes Arthur's life can also be such a sign. She writes 'Surely persons with even the most profound limitations have a vocation; they are 'sign' in the biblical sense, pointing beyond themselves' (Young 2013: 285). She goes on to conclude that she has made 'the move from struggling with theodicy to seeing that, through Arthur, I have privileged access to the deepest truths of Christianity' (2013: 404).

As Michael Gorman puts it,

a life of faith, hope, and love; of Christlike self-giving... above all is something [believers] do, something indeed they are. And people actually are something something that stands in some sense in contrast to normal living - they will provoke reactions: sometimes quite positive, sometimes more negative (Gorman 2015: 48, emphasis in original).

This is a timely reminder that the human response to signs of the redeeming divine reality may well be rejection. 'He came to his own and his own received him not' (Jn 1.11, KJV).

So we are developing a picture of an intensified divine immanence in the world, spreading with the spread of Christlike self-giving (note not necessarily of the institutional Christian Church, but of those lives that are authentically Christlike). That culminates in Pauline eschatology in the consummated state of creation when to an unprecedented degree 'God will be all in all'. In that eschatological state, there will be no need for God to communicate Godself through signs; glory will be the direct manifestation of Godself. The world will be transparent to the immanence of God (Southgate 2018: 29-30).

As the Fourth Gospel continually emphasises, Jesus lived as one sent by the Father, the quality of his life always pointed beyond himself. To contemplate, through the work of the Spirit, the quality of the life of the one sent is to be led into all truth, to know (at least 'in a glass darkly', 1 Cor 13:12, KJV) the quality of the life of the sender.

How does that relate to our theme of immanence and transcendence? I am suggesting that the intensified and particular immanence that we see in the Incarnation can be communicated, through the mediation of the Spirit, to human beings. Human persons can be signs of that immanence. More, they can even come to share in it. At the climax of Jesus' High Priestly Prayer in the Gospel of John we read:

As you, Father, are in me and I am in you, may they also be in us, so that the world may believe that you have sent me. The glory that you have given me I have given them, so that they may be one, as we are one, I in them and you in me, that they may become completely one, so that the world may know that you have sent me and have loved them even as you have loved me (Jn 17:21-23).

What might this model of missional immanence through the Incarnation and Christ's signification of the quality of the divine life suggest about divine transcendence? First, it 
insists, with Primavesi, on the epistemological transcendence of God, who will always be beyond our understanding. In the face of that mystery all our doctrinal syllogisms are as Aquinas saw, 'so much straw'. But here at least is a possible direction of travel.

Immanent in all creation is the Trinity of self-giving love whose overflow gave rise to creation in the first place. God, in John Haught's words, 'pours the divine self into the world in an act of unreserved self-abandonment' (Haught 2000: 48). Thus creatio ex nihilo can be configured not as arbitrary mastery but as uttermost gift (Oliver 2017: 14356). Also, the perfect mutuality of Son and Father subverts Ruether's concern about the subordination of immanence to transcendence. Mutual indwelling is the property of the whole Trinity from before the foundation of the world (cf. Jn 17:5).

Our problem then starts to seem like the recovery of transcendence, rather than its over-dominance. I suggest we look for transcendence precisely in the self-giving that is the internal dynamic of this model of Trinity. We might think of the image and likeness of God as being the human self-giving response to the self-giving love of God (Southgate 2011). That is why the Pauline letters can call Christ the true image of God (Col 1:15;2 Cor 4:4). His response to the Father's poured-out love was perfect. But self-giving that is only human is limited by all sorts of factors, not least the deep self-interest that is a necessary property of our evolutionary inheritance. Divine transcendence may be thought of as the unimaginable perfection of that self-giving that is immanent in the life of the Trinity, and hence perfectly immanent in the life of the world.

Denis Edwards, drawing on Khaled Anatolios' work on Athanasius, says that because of the divine attributes of loving kindness and mercy, God can transcend God's transcendence (Edwards 2018). But I am suggesting something slightly different, namely that the crucial form of God's transcendence is precisely in that loving kindness and mercy. Yes, God is ontologically, epistemologically, spatially, transcendent, transcendent also in terms of lordliness and glory, but where transcendence is truest to the Christian vision is where it is seen in the uttermost of self-giving. That is the sense in which divine transcendence, in the Christian vision, genuinely can be good news for the world.

The giving of the divine Son for the life of the world, as immanent sign but also as the one who draws disciples into the life of God, that which Christians confess as the supreme divine communication and gift of intensified immanence, is a hint to us that transcendence is to be found in that very immanence. Thus transcendence, in the Christian vision, can be found not only in unknowability, but also in Trinity, in that relationship of love between Persons that is perfectly transcendently self-giving. And the true human vocation is a quality of life in the image of that transcendent self-giving, made possible by the immanent gift of Christlikeness after the example of the Incarnate Son.

I began by outlining the difficulty in holding divine transcendence and immanence in healthy relationship in Christian theology, a difficulty particularly emphasised by ecofeminists such as Sallie McFague. Starting from a very different place from McFague's recent essay, in terms of glory as sign rather than the predicament of global climate change, I have come in this brief sketch to a very similar place to the one she outlines - divine transcendence to be found in immanence, and through the relationships Christians confess as Trinity.

\section{Bibliography}

Bauman, W., 2009. Theology, Creation and Environmental Ethics: from Creatio ex Nihilo to Terra Nullius. London: Routledge. 
Clayton, P., 2007. On Divine and Human Agency: Reflections of a Co-Laborer. In P. Clayton (ed.), All That Is: A Naturalistic Faith for the Twenty-First Century. Minneapolis, MN: Fortress Press, 163-75.

Edwards, D., 2018. Christopher Southgate's Compound Theodicy: Parallel Searchings. Zygon: Journal of Religion and Science 53(3): 680-90..

Finlan, S., 2007. Can we speak of Theosis in Paul? In M. J. Christensen and J. A. Wittung (eds.), Partakers of the Divine Nature: The History and Development of Deification in the Christian Traditions. Grand Rapids: Baker Academic, 68-80.

Goranson Jacob, H. and Wright, N. T., 2018. Conformed to the Image of His Son: Reconsidering Paul's Theology of Glory in Romans. Downers Grove, IL: Inter-Varsity Press.

Gorman, M., 2015. Becoming the Gospel: Paul, Participation and Mission. Grand Rapids: Eerdmans.

Harrisville, R. A., 2006. Fracture: The Cross as Irreconcilable in the Language and Thought of the Biblical Writers. Grand Rapids: Eerdmans.

Haught, J., 2000. God after Darwin: A Theology of Evolution. Oxford: Westview.

Keller, C., 2002. The Face of the Deep: A Theology of Becoming. New York: Routledge. McFague, S., 1993. The Body of God: an ecological theology. London: SCM Press.

McFague, S., 2017. Reimagining the Triune God for a Time of Climate Change. In G. J. Kim and H. Koster (eds.), Planetary Solidarity. Minneapolis: Fortress Press, 101-18.

Moltmann, J. 1985. God in Creation, transl. M. Kohl. London: SCM Press.

Moore, A., 1904 [1889]. The Christian Doctrine of God. In C. Gore (ed.), Lux Mundi. London: John Murray, 41-81.

Oliver, S. 2017. Creation: A Guide for the Perplexed. London: Bloomsbury.

Oord, T. J., forthcoming. God's initial and ongoing creation. In H. P. Koster and E. M. Conradie (eds.), Christian Theology and Climate Change. London: T.\&T. Clark.

Palmer, C., 1992. Stewardship: A Case Study in Environmental Ethics. In I. Ball, M. Goodall, C. Palmer and J. Reader (eds.), The Earth Beneath: A Critical Guide to Green Theology. London: SPCK, 67-86.

Peacocke, A. R., 1998. Biological Evolution - A Positive Theological Appraisal. In R. J. Russell, W. R. Stoeger, SJ, and F. J. Ayala (eds.), Evolutionary and Molecular Biology: Scientific Perspectives on Divine Action. Vatican City: Vatican Observatory and Berkeley, CA: Center for Theology and the Natural Sciences, 357-76.

Peacocke, A. R., 2001. Paths from Science towards God: the end of all our exploring. Oxford: Oneworld.

Peacocke, A. R., 2004. Biological Evolution and Christian Theology. In A. R. Peacocke, Evolution: The Disguised Friend of Faith? Selected Essays. West Conshohocken, PA: Templeton Foundation Press, 22-49.

Peacocke, A. R., 2007. All That Is: A Naturalistic Faith for the Twenty-First Century, ed. P. Clayton. Minneapolis, MN: Fortress Press.

Primavesi, A. 2003. Gaia's Gift: the Earth, Ourselves and God After Copernicus. London: Routledge.

Robinson, A., 2010. God and the World of Signs: Trinity, Evolution, and the Metaphysical Semiotics of C. S. Peirce. Leiden: Brill.

Robinson, A., 2014. Traces of the Trinity: Signs, Sacraments and Sharing God's Life. Cambridge: James Clarke.

Ruether, R. R., 1998. Introducing Redemption in Christian Feminism. Sheffield: Sheffield Academic Press.

Santmire, H. P., 2008. Ritualizing Nature: Renewing Christian liturgy in a Time of Ecological Crisis. Minneapolis: Fortress Press. 
Savage, T. B., 1996. Power through Weakness: Paul's Understanding of the Christian Ministry in 2 Corinthians. Cambridge: Cambridge University Press.

Southgate, C., 2008. The Groaning of Creation: God, Evolution and the Problem of Evil. Louisville, KY: Westminster John Knox Press.

Southgate, C., 2011. 'Re-reading Genesis, John and Job: A Christian's Response to Darwinism', Zygon 46(2), 370-95.

Southgate, C., 2018. Theology for a Suffering World: Glory and Longing. Cambridge: Cambridge University Press.

von Balthasar, H. U., 1982. The glory of the Lord: a theological aesthetics Vol. 1, Seeing the form, transl. E. Leivà-Merikakis, ed. J. Fessio, SJ and J. Riches. Edinburgh: T\&T Clark.

Young, F., 2013. God's Presence: A Contemporary Recapitulation of Early Christianity. Cambridge: Cambridge University Press. 